\title{
Appraisal of Effect of Problem-Based Learning Strategy on Chemistry Students' Academic Achievement in Senior Secondary Two in Mole Concept in Ahoada West Local Government Area, Rivers State
}

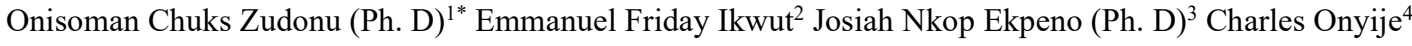 \\ 1. Department of Chemistry Education, Federal College of Education (Technical), Omoku, \\ P.M.B 11, Rivers State, Nigeria \\ 2. Department of Science Education, University of Port Harcourt, P.M.B 5323 Choba, East- \\ West Road, Por Harcourt, Rivers State, Nigeria \\ 3. Department of Chemistry Education, Federal College of Education (Technical), Omoku, \\ P.M.B 11, Rivers State, Nigeria \\ 4. Department of Chemistry Education, Federal College of Education (Technical), Omoku, \\ P.M.B 11, Rivers State, Nigeria \\ *E-mail of the corresponding author: Onyije.charles304@fcetomoku.edu.ng
}

\begin{abstract}
The study determined the effect of problem-based learning strategy on chemistry students' academic achievement in SSII in Ahoada West local government area of Rivers State, Nigeria. Two research questions and two hypotheses were used for the study. A quasi experimental, pre-test and post-test design was employed for the study. A total of 80 SSII Chemistry students out of 312 from ten senior secondary schools in Ahoada West LGA were selected through stratified random sampling technique as the sample for this study. One instrument was utilized for this study; namely, Chemistry Achievement Test (CAT) developed by the researchers and was validated by three experts, two from Chemistry education unit and one from research method unit. All from the department of science education, University of Nigeria, Nsukka and was used for data collection. The reliability coefficient of the instrument was established using 20 SSII Chemistry students from a different secondary school that is not part of the study, but the students do possess the same status. Cronbach's alpha reliability estimate was used to determine the internal consistency of the items which was found to be 0.81 . The data collected were analyzed using mean, standard deviation and ANCOVA. The study showed that students in the experimental group achieved significantly higher mean scores than students in the control group. $\mathrm{P}=0.000<0.05$. There was no significant difference in mean achievement of male and female students who were exposed to PBL strategy, $\mathrm{P}=0.072>0.05$. Based on these findings, the researchers recommended among others that Chemistry teachers should be encouraged to utilized PBL strategy as a means of instructions since it enhanced achievement of students in Chemistry.
\end{abstract}

Keywords: Problem-Based Learning, Academic Achievement, Senior Secondary School II Students, Gender, Chemistry

DOI: $10.7176 / \mathrm{CMR} / 12-6-05$

Publication date: August $31^{\text {st }} 2020$

\section{Introduction}

Today's society is characterized by an increasing rate of complex vicissitudes, challenges, and problems (Barnett and Coat, 2005; Jackson, 2005) requiring individuals to possess certain skills. It is a society with myriads of complexities, and indistinctness with environmental, social, political, and economic pressures. The labour market is also dynamically competitive, demanding employees who can fruitfully meet workplace challenges, invent, transform, act quickly, and present effective solutions to problems yet unknown. This type of society encourages the learners to possess creativity, collaboration, communication, and critical thinking skills, which have been described as the 21 st century skills, to be able to cope and contribute positively to the society. Meanwhile, the development of any nation has been linked to its scientific and technological development. According to Adikwu (2012), any nation that wants to experience economic growth must have strong commitment toward science. This implies that science plays a significant role in the economic, technological, political, and environmental development of any nation because science has permeated all facets of human life. The universal recognition of the above suggestion is responsible for the prime position that has been accorded to science and chemistry alike worldwide. Within the context of science education, chemistry has been identified as a very important school subject and its importance in scientific and technological development of any nation has been widely reported (Zudonu, 2013 \& Zudonu, 2018). It was as a result of the recognition given to chemistry in the development of the 
individual and the nation that is made a core-subject among the natural sciences and other science-related courses in the Nigerian education system. Its inclusion as a core subject in science in the secondary school calls for the need to teach it effectively. This is because effective science teaching can lead to the attainment of scientific and technological greatness. Chemistry teaching can only be result-oriented when students are willing and the teachers are favourably disposed, using the apt methods, strategies and resources in teaching the students. With the current increase in scientific knowledge in the world, much demand is placed, and emphasis is positioned on the teacher, the learner, the curriculum and the environment in the whole process of teaching and learning of Chemistry. Despite the importance of Chemistry to mankind and the efforts of researchers to improve on its teaching and learning, the achievement of students in the subject remains low in Nigeria. Among the factors that have been identified are, poor methods of instruction (Osuafor, 1999 and Zudonu, 2013) teacher's attitude (Aghadiuno, 1992), laboratory inadequacy (Okegbile, 1996; Raimi, 1998; Bajah, 1999 and Adeyegbe, 2005), and poor science background (Oshokoya, 1998 and Adesoji, 1999).

Papanastasiou (2001) reported that those who have positive attitude toward science tend to perform better in the subject. The affective behaviours in the classroom, achievement, and science attitudes are learned (George and Kaplan, 1998), the teachers play a significant part during the learning process and they can unswervingly or vicariously influence the student's attitudes toward science which its consequence can influence students' achievement. Teachers are, invariably, role models whose behaviours are easily imitated by students. What teachers like or dislike, appreciate and how they feel about their learning or studies could have a significant effect on their students. By extension, how teachers teach, how they behave and how they interact with students can be more dominant than what they teach. Student's attitude toward the learning of chemistry is a factor that has long attracted attention of researchers. Ojo (1989), Zudonu (2013) and Adesokan (2002) asserted that in spite of realization of the recognition given to Chemistry among the science subjects, it is evident that students still show negative attitude towards the subject, thereby leading to poor performance and low enrolment. The achievement of students in Chemistry is also reported to be causally influenced by the previous experience of the students in integrated science when they were in their JSS classes. A student cannot learn Chemistry effectively without going through some experiences in integrated science (Oshokoya, 1998 and Adesoji, 1999). Other factors that may have causal relationships with students' academic achievement in science, particularly, Chemistry include teacher attendance at Chemistry workshop, laboratory adequacy, class size and school location. One of the fundamental problems facing Chemistry teaching today is the question of how current the professional teachers are. Most teachers who have been employed in the past decades have been doing the same thing, the same way all along. They have no knowledge of the current ideas and innovations that have taken place in the educational field in the recent past. What account for this is that teachers have not been given the opportunity for re-training (Ogunbiyi, 2004 and Zudonu, 2018). They therefore recommended that teachers should be encouraged to go for workshop training in their areas of specializations. This persistent poor achievement in Chemistry and inappropriate methods of teaching portrays that the current educational pattern is puny or inappropriate (Oludipe \& Oludipe, 2010).

It is as a result of the need for these changes in instructional methods to enhance learning that the researchers intend to recommend a departure from the conventional lecture method of teaching to one of the most recent constructivist-based teaching strategies known as Problem-Based Learning (PBL) strategy. Conventional lecture method is the method of teaching that is characterized by the following: it is teacher-centered. It inhibits active participation of students in the classroom; it reduces students to mere note-taking and passive listeners and learners, perception and assimilation and accommodation of the subject matter is slow. It is examination oriented.

It is in view of this that, this study used PBL strategy to find out its effect on students' learning. PBL represents a paradigm shift from conventional teaching (Hung, 2011). This is because PBL strategy is students-centered learning theory, where learning is carried out in small groups, typically 6-9 students per group; poor-structured problem that requires further research forms the basis for the organized focus of the group and stimulates learning (Briggs, 2015; Vincent \& Renee, 2015). PBL strategy is a learner-centered theory because the learner is encouraged to construct his/her knowledge by dealing with real life situation (Shweta, 2015).

The role of the Chemistry teacher is to facilitate the student's learning by providing opportunities for learners to engage in constructive processes, Torp and Sage (as cited in Briggs, 2015).

\section{Statement of the Problem}

Research have shown tiny or scanty records to attest to the effects of Problem-based learning strategy on students' academic achievement in chemistry or whether it is gender dependent or not. The problem of this 
study therefore is to investigate the effect of Problem-Based Learning strategy on SSII students' academic achievement in Chemistry in Ahoada West.

\section{The Purpose of the Study}

The purpose of this study is to appraise the effect of Problem-Based Learning strategy on Chemistry students' academic achievement in SS II. Specifically, the study sought to achieve the following:

1. To investigate the academic achievement of SS II Chemistry students taught with PBL strategy and those taught in a conventional way.

2. To determine if there is difference in the academic achievement of male and female students when taught Chemistry using PBL strategy.

\section{Research Questions}

Two research questions guided the study:

1. What are the differences in the academic achievement of SS II chemistry students taught using PBL strategy with those taught with conventional method?

2. What are the differences in the academic achievement of male and female SS II Chemistry students taught using PBL method?

\section{Hypotheses:}

Based on the research questions, the following null hypotheses were formulated and tested at 0.05 level of significance:

1. There is no significant difference in the academic achievement of SSII Chemistry students taught with PBL strategy and those taught in a conventional way.

2. There is no significant difference in the mean academic achievement of male and female SSII Chemistry taught using PBL strategy.

\section{Methodology}

The research design adopted for this study was quasi-experimental. Quasi experimental involves an existing group of participants who receive treatment and another existing group of participants as a control group (Harris, McGregor, Perencerich, Furuno, Zhu, Peterson \& Finkelstein, 2006). The experimental design allows the researchers to manipulate the independent variables in order to investigate its effects on the dependent variables. The quasi experimental design for this study was pre-test, posttest type. The intact classes were randomly assigned to experimental and control groups that were used. Both groups were taught the same Chemistry content as contained in their minimum academic requirement; the treatment group, were subjected to PBL strategy while in the control group, conventional lecture method was used.

The study was conducted in Ahoada West Local government area of Rivers State, Nigeria. The target population for this study comprised 312 SSII Chemistry students from 10 secondary schools in Ahoada West who offered Chemistry as one of their core subjects, as of the time this study was carried out. The sample for this study comprised of 80 SSII Chemistry students from ten co-educational schools. Ten schools were selected by stratified random sampling technique. Five of the schools were assigned as treatment groups and the other five as control group. The researchers developed Chemistry Achievement Test (CAT) for data collection. This was a 20-item test drawn from the topic mass and volume relationship. This was in tandem with the WAEC benchmark since the study was expected to improve the student's achievement at this level. The instrument was used for pre-test and post-test. 


\section{Validation of the Instrument}

Chemistry Achievement Test (CAT) was face-validated by three experts: two from Chemistry Education and one from Measurement and Evaluation, all in the department of Science Education, University of Nigeria, Nsukka. Copies of the instrument and research questions for the study were made available to the experts. The experts were requested to assess the instrument on clarity of items, simplicity of vocabulary used, and appropriateness of the items or relevance of the items to the purpose of the study. Their observations, corrections and suggestions on instrument were incorporated to improve the final draft of the instrument.

\section{Reliability of the Instrument}

The Chemistry Achievement Test (CAT) was trial tested on twenty (20) Chemistry students from Bayelsa State which share similar characteristics with the area of the study. The data obtained were computed using Cronbach Alpha reliability estimate to determine the internal consistency of the items in the instrument. Cronbach Alpha reliability index was used because the items were polytomous or non-dichotomously scored. The reliability estimates or coefficient obtained was 0.82 and it was consistent for this study.

\section{Method of Data Collection}

Permission was sought from the school authority of the selected schools to enhance data collection. 80 copies of Chemistry Achievement Test (CAT) were administered to SSII chemistry students during pre-test and post-test exercises respectively, this was undertaken by the researchers and the trained Chemistry teachers at the sampled schools. The completed copies of the administered test items were retrieved back.

\section{Method of Data Analysis}

The data collected were analyzed using the statistical tools of mean scores, standard deviations and ANCOVA. The descriptive statistics of mean scores, standard deviations were used to answer the research questions while the inferential statistics of ANCOVA of independent variables were used to test the null hypotheses at 0.05 level of significant.

\section{Results \\ Research Question 1}

What is the difference in mean academic achievement scores of SSII Chemistry students who were taught using Problem-Based Learning strategy and those who were taught using Conventional Lecture Method?

Table 1: Mean and Standard Deviation of Achievement of Chemistry Students who were taught using PBL Strategy.

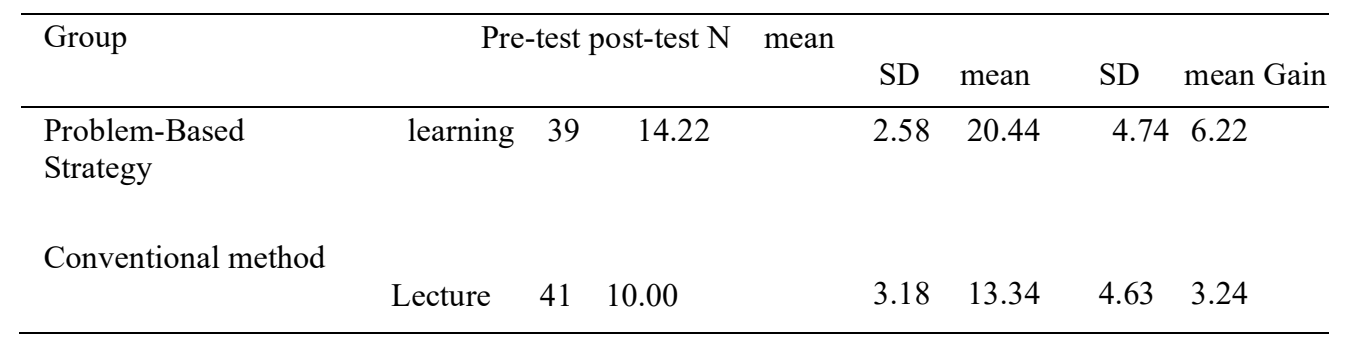

Table 1 presents the mean and standard deviation of academic achievement for pre-test and post-test of students taught with PBL strategy and those who were taught with conventional lecture method. It was observed that the pre-test mean for the two categories were 14.22 and 10.10, respectively. The table also shows that the post-test means achievement of Chemistry students taught using Problem-Based Learning strategy and those taught using 
conventional lecture method were 20.44 and 13.34, respectively. It was observed that the mean gain of the two categories, the pre-test and the post-test were 6.22 and 3.24, respectively. The mean gain of the experimental group was 6.22. That is, the mean gain was higher than the control group's mean gain which was 3.24. The experimental group achieved higher than the control group.

\section{Research Question 2:}

How do male and female students differ in mean academic achievement in Chemistry when taught with problemBased Learning strategy?

Table 2: Mean Academic Achievement of Male and Female Chemistry Students taught using Problem-Based Learning Strategy.

\begin{tabular}{llllr}
\hline Gender & & Pre-test & Post-test & Mean Gain \\
\hline Male & Mean & 13.75 & 21.25 & 7.50 \\
& $\mathrm{~N}$ & 20 & 20 & \\
& S.D. & 3.09 & 5.49 & 5.11 \\
Female & Mean & 14.47 & 19.58 & \\
& $\mathrm{~N}$ & 19 & 19 &
\end{tabular}

Table 2 shows the result of the mean academic achievement of male and female Chemistry students taught with Problem-Based Learning strategy. From Table 2, it was observed that students were consistent academically before treatment (Pre-test) with mean scores of 13.75 and 14.47 for male and female students, respectively. The Table also shows the mean gain between pre-test and post-test mean of the male students was 7.50. This mean gain was higher than the female's mean gain which was 5.11 . This gives a mean difference of 2.39 in favour of the males. The male students achieved slightly higher than the female students.

\section{Hypothesis 1}

There is no significant difference in the mean achievement scores of Chemistry students who were taught with Problem-Based Learning strategy and conventional lecture method.

Table 3: ANCOVA Test of Difference in the Mean Achievement Scores of Chemistry Students who were taught with Problem-Based Learning Strategy and Conventional Lecture Method

\begin{tabular}{|c|c|c|c|c|c|c|}
\hline \multirow{2}{*}{$\begin{array}{l}\text { Source } \\
\text { Corrected Model }\end{array}$} & \multicolumn{2}{|c|}{ Type III Sum of Squares Df } & \multicolumn{2}{|c|}{ Mean Square F } & \multirow{2}{*}{$\begin{array}{l}\text { Sig. } \\
.000\end{array}$} & \multirow{2}{*}{$\begin{array}{l}\text { Partial Eta Squared } \\
.453\end{array}$} \\
\hline & $2131.882^{\mathrm{a}}$ & 2 & 1065.941 & 71.551 & & \\
\hline Intercept & 959.573 & 1 & 959.573 & 64.411 & .000 & .271 \\
\hline Type & 1002.408 & 1 & 1002.408 & 67.286 & .000 & .280 \\
\hline Strategy & 1309.333 & 1 & 1309.333 & 87.888 & .000 & .337 \\
\hline Error & 2577.300 & 173 & 14.898 & & & \\
\hline Total & 41366.000 & 176 & & & & \\
\hline Corrected Total & 4709.182 & 175 & & & & \\
\hline
\end{tabular}

Table 3 is ANCOVA table for the significant difference in the mean achievement scores of Chemistry students who were taught with Problem-Based Learning strategy and conventional lecture method.

The table gives $\mathrm{F}(1,173)=87.888$ and $\mathrm{P}=0.000$. Since $\mathrm{P}<0.05$, the null hypothesis was rejected. This means that 
there was a significant difference in the mean achievement scores of Chemistry students who were taught with Problem-Based Learning strategy and conventional lecture method. The partial eta value of 0.337 means that the effect size is $33.7 \%$ which is reasonable.

\section{Hypothesis 2}

There is no significant difference in the mean achievement scores of male and female Chemistry students who were taught using Problem-Based learning strategy.

Table 4: ANCOVA Test of Difference in the Mean Achievement Scores of Male and Female Chemistry Students who were taught with Problem-Based Learning Strategy

\begin{tabular}{lrrrrrr}
\hline Source & Type III Sum of Squares df & Mean Square & F & Sig. & Partial Eta Squared \\
& & & & & & .431 \\
\hline Corrected Model & $906.221^{\mathrm{a}}$ & 2 & 453.111 & 34.506 & .000 & .360 \\
Intercept & 673.097 & 1 & 673.097 & 51.259 & .000 & .413 \\
Type & 839.104 & 1 & 839.104 & 63.902 & .000 & .020 \\
Sex & 24.033 & 1 & 24.033 & 1.830 & .179 & \\
Error & 1194.938 & 91 & 13.131 & & & \\
Total & 28625.000 & 94 & & & & \\
Corrected Total & 2101.160 & 93 & & & & \\
\hline
\end{tabular}

Table 2 is ANCOVA table for the significant difference in the mean achievement scores of male and female Chemistry students who were taught using Problem-Based Learning strategy.

The table gives $\mathrm{F}(1,91)=1.830$ and $\mathrm{P}=0.179$. Since $\mathrm{P}>0.05$, the null hypothesis was not rejected. This means that there was no significant difference in the mean achievement scores of male and female chemistry students who were taught using Problem-Based Learning strategy. The partial eta shows an effect size of $0.020(2 \%)$ which is not reasonable meaning that gender influence is not substantial.

\section{Discussion of Findings}

The research has revealed that students in experimental group achieved higher than students in control group. This means that students taught using the PBL strategy performed significantly better in chemistry students' academic achievement test than their counterparts who were taught using the conventional lecture method. The reason for the better achievement could be the teaching method which is a significant factor in students' achievement in Chemistry. This is because the method provided opportunities for students to interact, explore, ask questions and experience real contact with Chemistry materials and equipment used in teaching the concepts. By so doing, students actively participated in making discoveries through poor-structured questions and discussing them among their peers in the group.

This confirms the findings of Afolabi and Akinbobola (2009), and Oludipe and Oludipe, (2010), who found in their researches that students taught using PBL strategy performed better than those taught using conventional lecture method which led to higher achievement in physics among SSII students as well as integrated science.

Based on gender, the study showed that male students had a mean achievement test score higher than the female students, but the mean difference was statistically insignificant. This indicates that gender has no significant effect on the achievement of Chemistry students taught with PBL strategy. This result agrees with Afolabi and Akinbobola (2009) who found that gender has no significant effect on the performance of physics students when taught using PBL strategy. Also, Oludipe (2012) found that there was no statistically significant difference in the pre-test, post-test and delayed post-test academic achievement mean scores of male and female students. 


\section{Conclusion}

Based on the findings, it was concluded that the use of PBL strategy enhances students' academic achievement in chemistry than the use of conventional lecture method. With the use of PBL strategy, the study revealed no gender disparity in achievement. This therefore implies that if the right instructional strategy is used by Chemistry teachers, it is believed that both male and female students will perform equally well in chemistry.

\section{Recommendations}

Based on the findings and their implications, the following recommendations were made:

i. Chemistry teachers should use PBL strategy in teaching Chemistry since it is found to enhance students' academic achievement. It should be used more particularly in areas where topics pose to be difficult and abstract.

ii. Teacher training institutions should include PBL strategy in the science methodology content and make provision to train pre-service teachers in the use of PBL strategy.

iii. Authors of Chemistry should include activities that will encourage the use of Problem-Based Learning strategy by the teachers and students.

iv. Chemistry Curriculum developers should make provision for and emphasize on the use of PBL strategy by the curriculum implementers (Practitioners) because this strategy has enhanced students' achievement in Chemistry.

\section{References}

Adesokan, C. O (2002). Students Attitude and gender as Determinants of Performance in JSS Integrated Science. Unpublished B.Ed. Project University of Nigeria.

Adesoji, F. A. (1999). Knowledge of integrated science as pre-requisite capability for First year senior secondary school sciences and implication for teacher education in Abimbade, A. (eds). Teaching and teacher preparations in the Twenty first century Department of Teacher Education pp 77-81.

Adikwu, M. U. (2012). Curriculum Development in Science, Technology and Mathematics (STM) Education. A Keynote Address presented at the 49th Annual Conference of Science Teachers Association of Nigeria, Yenagoa.

Afolabi, F., \& Akinbobola, A. O. (2009). Constructivist Problem-Based Learning Technique and the Academic Achievement of Physics Students with Low Ability Level in Nigerian Secondary Schools. International Journal of Physics \& Chemistry Education, 1(1),45-51.

Agbadiuno, M.C.K. (1992): A path-analytic study of cognitive style. Understanding of science and Attitudinal variables as correlates of Achievement in Chemistry. Unpublished Ph.D. Thesis of University of Ibadan, Ibadan

Bajah, S. T. (1999). The challenges of science technology and teacher education in Nigeria. Beyond the year 2000. African Journal of education (91), 43-49

Barnett, R., \& Coat, K. (2005). Supercomplexity and the Curriculum in Higher Education. Buckingham, 
UK: Open University Press, McGraw Hill Education.

Briggs, S. (2015). 10 Tips for effective problem-based learning. The ultimate instructional solution. Retrieved from www.opencolleges.edu.au/infor

Harris, A. D., McGregor, J. C., Perencevich, E. N., Furuno, J. P., Zhu, J., Peterson, D. E. \& Finkelstein, J. (2006). The use and interpretation of quasi-experimental studies in medical. PubMed 13(1): 1623

Hung, W. (2011). Theory to reality: A few issues in implementing problem-based learning. Educational Technology Research and Development. 59(4): 529-552

Jackson, N. (2005). Making higher education a more creative place. Journal for the Enhancement of Learning and Teaching, 2 (1), 14-25. Available from: http://www.uhra.herts.ac.uk/bitstream/handle/2299/2595/902905. pdf; sequence=1. [Last retrieved on 2017 Dec 26].

Ogunbiyi, O. (2004). New challenges in the Methodologies of Teaching, A case of in-service school teachers in Elaturoti, F and Babarinde K (eds) Teachers' Mandate on Education and Social Development in Nigeria.

Ojo, M. O. (1989). The differential Effectiveness cooperative competitive and individual's Goal structures on students' performance in chemistry. Unpublished $\mathrm{Ph}$. D Thesis, University $\quad$ of Ibadan, Ibadan.

Okegbile S.O. (1996). Evaluation of practical lessons in science. Being a paper presented at the managerial conference of school of education at Federal college of Education. Osiele Abeokuta.

Oludipe, B. \& Oludipe, D. I. (2010). Effect of constructivist-based teaching strategy on academic performance of students in integrated science at the Junior Secondary School level. In Educational Research and Reviews. 5(7): $347-353$

Osokoya M. M (1998). Some determinants of secondary school students'academic achievement in Chemistry in Oyo State. Unpublished Ph.D. Thesis University of Ibadan, Ibadan

Osuafor, A. M (1999). Extent of use of Research findings on Structural Strategies in Science Education. Journal of science Teachers Association of Nigeria. 341 \& 3, pp. 102-112

Papanastasiou, E. C., (2001) Willingness to follow Math related careers among seniors in Math Classes. The case of Cyprus Manuscripts submitted for publication. Science Education International 13(2) 20-21.

Raimi, S. M. (1998). Gender differences in Acquisition of Practical skills. Journal of School of Science and Education 1:28-40

Shweta, V. (2015). Problem-based learning strategy in E-learning courses. From www.blog.commlabindia.com/elearning-design/problem-based

Vincent, R. \& Renee, L. (2015). Problem-based learning: Six steps to Design, Implement and Assess. From www.facultyfocus.com/articles/instructiona_design/prot

Zudonu, O.C. (2013). Effects of laboratory instructional methods on students' conceptual change, achievement and attitude to some chemistry concepts at senior secondary school level. (Unpublished M.Ed Thesis), Nsukka: University of Nigeria.

Zudonu, O. C. (2013). Effect of Inquiry Teaching Method on Students' Achievement in Separation Techniques in Chemistry in Senior Secondary School 1. Nigerian Journal of Education Science and Technology (NIJEST?). Vol. 2. No. 1. (Page 127-138).

Zudonu, O. C. (2018). Teachers'Utilization of Research Findings on Chemistry Teaching Methods in Secondary Schools in Rivers State, Nigeria. An Unpublished Ph.D Thesis. 